\title{
Narrating European integration: Transnational actors and stories
}

\section{Authors:}

Wolfram Kaiser, Professor of European Studies, University of Portsmouth wolfram.kaiser@port.ac.uk

Richard McMahon, Marie Curie Senior Research Fellow, University of Portsmouth rychumac@yahoo.com

\begin{abstract}
:
This article introduces the special issue on narrating European integration. Narratives, or stories, are a key mechanism for constructing individual and collective identities, and other politically important elements of discourse. The articles in this special issue go beyond most existing work on narratives. First, they examine the actors and networks, ranging from EU institutions to political parties and social groups, which create, foster and disseminate narratives. Second, they address major narratives and sets of narrating actors of at least a partly transnational nature. Third, the authors transgress disciplinary boundaries, drawing on contemporary history, sociology, political science and cultural studies.
\end{abstract}

Keywords: European integration; identity; narratives; myths; transnational actors. 


\section{Narrating European integration: Transnational actors and stories}

This special issue explores narratives of European integration, broadly conceived, in politics, society, and culture. It contributes to the growing literature on the structures, functions, and characteristics of narratives and their contestation within and across societies. Though narratives can have lasting impact on individual or collective identities, research on their role has only just begun to flourish in the fields of European Studies and European Union (EU) studies. The articles in this special issue go beyond most existing work in three ways. First, they broaden out the study of narratives by closely examining the actors and networks in politics, society, and culture which create, foster and disseminate narratives. Second, they do not treat isolated country cases. Instead, they address major narratives of at least a partly transnational nature - narratives developed and advanced by actors, ranging from EU institutions to political parties and social groups. These are themselves transnationally constituted or at least draw on transnational connections and learning processes. Third, to reconstruct these transnational actors and narratives, the authors transgress disciplinary boundaries, drawing on contemporary history, sociology, political science and cultural studies.

Like most academic literature, we define narratives as a series of events or developments told, more or less cohesively, along a storyline or plot (Kaiser, 2015, p. 365), like the rags to riches story of Ireland's Celtic Tiger that Wolf Schünemann mentions in his article. The concept's roots in literary studies go back to the late 1950s, and several decades earlier in Russian language studies (Czarniawska, 2004, pp. 1-2). However, it gained wider academic currency after the so-called linguistic turn of the 1970s and 1980s (Maza 1996, pp. 1493-95; Shenhav, 2005, pp. 76-78), especially through concepts of 'grand', 'master' and 'meta' narratives originally developed by Hayden White (1973) and Jean-François Lyotard (1979). Many 
historians, sociologists, anthropologists, cultural studies scholars and others eagerly engaged with the linguistic turn. They assume that the motivations behind social (including political) interpretations and actions are as often swayed by cultural habits, as by attempts to maximize the individual or group interests that rational choice-informed literature emphasizes.

More recently, research in a growing number of academic disciplines has used the concept of narrative as a key to understanding discourse and its impact on politics, society, and culture, not least because it offers an indispensable antidote to 'the essentializing tendencies of “identity politics” around categories like race, sex, and gender' (Hammack \& Pilecki, 2012, p.77). Moreover, human beings have a 'natural tendency to think in narratives' (Shenhav 2005, p. 76). This gives storytelling its unrivalled power to make ideas about 'cultural, socioeconomic and political developments' seem significant, understandable and plausible (della Sala, 2010, p. 4; Kaiser 2015, p. 2).

For this reason, psychologists have been increasingly captivated by narratives since the 1980s. Some rate them as our 'primary' way of linking 'the individual mind' to political and social realities and investing emotionally in them (Hammack \& Pilecki, 2012, pp.76-78). The coherent identities of individuals and social groups depend heavily on the sense of continuity that narratives provide (Hammack, 2008, pp. 10-11). Crucially, narratives do not just describe what happens. They construct how we perceive, remember and tell stories about what happens (Maza 1996: 1495; Roberts 2006: 710). The story we believe in influences how we react, engage, make demands and more generally, seek to shape our social and political environment. Parables and epics have therefore been mainstays of socialisation throughout human history, and they are formidable political weapons. Master narratives have for example played a key role in the social construction of nations and in the political integration of states since the nineteenth century. Nationalists have narrated, and continue to narrate, key 
events of their countries' histories as episodes in a struggle for national independence, security, power or glory (Anderson 2000).

This article will first set out the special issue theme of narratives in European integration. It will then introduce the articles and their individual and collective contribution to understanding these stories of integration and the roles of actors and networks in telling them. The article will go on to explore theoretical, conceptual and methodological issues of researching actors and narratives, and how the authors deal with them, before ending with some concluding comments.

\section{Narratives in European integration}

This special issue focusses on narratives that are widely disseminated in European society and can therefore have significant political impact. Such narratives have been crucial in defining myths about the origins of the present-day EU as well as its spatial scope, political finality and policy objectives. Such narratives of European integration seek to explain it as a 'process', to legitimise (or call into question) the EU, its institutions and policies, or to describe, critically evaluate and contextualize them for citizens.

The EU's socio-economic crisis and political turmoil since 2008, including the possibility of individual member states like the United Kingdom leaving the organisation, has challenged the existing narratives that helped sustain public support for European integration. It has therefore stimulated political and academic interest in European narratives and discourse more generally. Sarah Maza identifies such crises as points when 'meanings have become indeterminate', allowing social actors to 'attempt to impose fixed meanings on social experience' (1996, p. 1500). Initially, many Europeans gave passive support to European 
integration, because it brought material benefits such as increased trade and prosperity as well as peace for Western Europe (della Sala, 2010, p. 3). Following early left-wing criticism of the EU as a driver of economic liberalisation at the expense of social security and stability from the 1970s onwards, the troubled ratification of the Maastricht Treaty in 1992-3 accelerated the breakdown of this 'permissive' consensus (Hooghe and Marks 2009), and initiated increasingly heated debate over what is called the EU's democratic deficit. As subsequent treaty changes up to the 2009 Lisbon Treaty hugely increased the EU's powers and ambitions, more politicians and citizens began to reject deeper integration outright or demand that it be matched by greater democratic legitimacy, accountability, and transparency in its institutions and policy-making processes.

Many embattled political leaders now see solid public identification with the EU, based on some kind of shared cultural identity and political allegiance to its institutions, as the only solution to the EU's legitimacy crisis. In the early years of the European Community, the European Commission in particular very much focussed on improving the lot of citizens through 'output' in the form of beneficial legislation that helped to break down national barriers and implement the four freedoms, including freedom of movement. Since then, it has somewhat modified this highly technocratic approach. The EU as a whole has for example made efforts to create some kind of European cultural identity and unity. Thus, in the 1980s the European Community introduced symbols like the European flag, anthem and day, in the hope that their use would foster some form of European constitutional patriotism and allegiance to EU institutions (Calligaro 2013; Manners 2011). The EU has redoubled these efforts at creating a more secure cultural basis for the European polity since the ratification crisis over the Maastricht Treaty - a crisis that dramatically highlighted that citizen support for European integration could no longer be taken for granted (Littoz-Monnet \& McMahon, 2013, p. 225). 
Why then has no previous collective publication foregrounded the crucial role of narratives in shaping European discourses and identity? By contrast, research in European Studies as a multi- and interdisciplinary field has, since the late 1990s, recognised and analysed other, related ideational factors such as identity (Risse, 2010), memory (Leggewie, 2011; Macdonald, 2013), myths (della Sala, 2010), norms (Manners, 2002), and culture (Shore, 2000) to some extent. Recent changes in political language may help explain why research on narratives is only just beginning to flourish in European Studies. Though political actors have always told stories as part of the art of persuasion, they and the general public have only recently begun consciously and openly to discuss narratives as powerful political tools and ask what new narrative, or narratives, could buoy up public support for European integration. Thus, the 'New Narrative for Europe' project, which ran during 2013-14 and is examined in Wolfram Kaiser's article in this special issue, marks the European Commission's first important foray into exploiting the notion and concept of narrative.

Narratives are one of many ideas about the importance and use of political discourse that have filtered into common and political currency from academia. Academic approaches to the relationship between politics and discourse may therefore explain the late uptake of the concept of narratives. Political scientists who study the EU initially concentrated on those products of discourse, such as identity, memory, myths, and norms, which have the most immediate impact on political outcomes. Frank Schimmelfennig (2001) and Helene Sjursen (2002) for example attributed the EU's decision to enlarge eastward after the end of the Cold War to it having become rhetorically entrapped in its own normative discourse.

This emphasis on political impact is also central to discussion by scholars of the EU of the concept of myth (della Sala 2010, p.2), which is closely related to that of narrative. They focus heavily on how myth 'distorts', in order to give 'intention a natural justification' (Strath, 2005, p.260), and some discursive elements that they discuss as myths have no apparent story 
structure at all (Hansen \& Williams, 1999, p. 240). By contrast, the political role and impact of narratives, like those of metaphors (Hülsse 2006), rituals, symbols (Manners 2011) or tropes, is often less immediately visible. However, narratives are essential building blocks and motors for politically important products of discourse, giving them their emotional force and direction (Kølvraa, 2016, p. 170). After all, stories are a key way of defining and reinforcing people's identities, or whom they fundamentally understand themselves to be, and therefore which moral codes and actions they consider appropriate (Somers 1994).

\section{Analysing actors and narratives}

The contributors to this special issue are exceptionally well placed to establish narratives as a key concept in European Studies and to analyse their role in European politics, society, and culture. They all have some disciplinary connections with political science. Adina Maricut for example works in the political science sub-field of public policy analysis, which is devoted to understanding institutional behaviour and policy processes. Wolf Schünemann is a scholar of comparative politics, hence his interest in exploring similarities and differences between national referendum debates and their transnational character. However, their research topics and interest in cultural dimensions of European integration take all authors beyond narrowly political-institutional concerns. Some work at the interface of political science with religious studies (Jim Guth) or draw on transnational history within the context of interdisciplinary European Studies (Wolfram Kaiser, Richard McMahon, Brent Nelsen). Nikola Petrović and Schünemann engage thoroughly with sociological concepts and insights. Ljiljana Radonić's interdisciplinary profile and track-record even includes elements of philosophy and theatre studies. As a result, their articles highlight and explore how political actors interact with 
intellectuals, artists, and citizens (Kaiser), academics (McMahon, Petrović), museum directors and curators (Radonić) and religious leaders (Nelsen and Guth) in attempts to produce narratives of European integration. Most articles analyse narratives in explicitly political speeches, manifestos, press reports, institutional documents and website forum comments, but McMahon, Petrović and Nelsen and Guth also examine academic and religious texts.

The articles cluster around two approaches to the present-day impact of political narratives in European integration. First, Kaiser, Maricut and McMahon focus on the use of narratives to support political agendas, which in turn respond to the persisting crisis of the EU. Examining evolving positions of the European Commission, Parliament and Council of Ministers on the free movement of persons, Maricut concludes that institutions develop particular entrenched narratives to support their vision of, and preferences for, a policy field. Kaiser focuses on one key institution, the Commission, and how it attempted to mobilise the concept of narrative in order to address the EU's legitimacy crisis and lack of public engagement. McMahon in turn examines EU Studies as the intellectual infrastructure of European integration and therefore a crucial informal institution. He traces the changing narratives that academics produce about European integration.

The other four articles also consider narratives that are used to advocate political positions on European integration. However they expand their focus to broad cleavages in the identity and culture of Europeans which shape and are shaped by narratives of integration. Schünemann looks at campaign narratives in three EU treaty referenda in order to examine a fundamental political issue for the EU, the emerging division between pro-Europeans, who have supported further deepening, and Eurosceptics. The other three articles address much older divisions. As Schünemann points out, a crucial factor structuring pro and anti-European positions is the traditional right-left divide in politics. Nikola Petrović traces the emergence of new pro- 
integration narratives among centre-left parties and public intellectuals in the 1990s. Many EU citizens traditionally either identify themselves with the left or the right in politics or are associated with them through family histories or social networks. This is even truer of the religious cleavage that Nelsen and Guth investigate, between Catholicism and Protestantism. By looking at the fundamentalist fringe of Protestantism, they argue that its cultural influence informs some forms of ingrained Eurosceptic narratives. Both narratives contrast with the dominant post-war pro-integration narrative of Christian Democracy - a narrative characterized by its predominantly Catholic origins, the belief in some kind of Christian cultural unity and a strong commitment to broadly federalist forms of integration (Kaiser, 2007). Finally, Radonić addresses another crucial cleavage, between east and west. She contrasts narratives in newer post-communist EU member states with those prevailing in Western Europe.

\section{Narratives of European integration}

As this brief outline suggests, contributors address major transnational narratives of European integration. Among them are the oldest central legitimising story about European integration as a promoter of peace and prosperity (discussed in Kaiser's article) and more recent narratives of the EU as a force for good, promoting human rights and other liberal values around the world (Maricut, Petrović). Radonić considers whether condemnation of the Holocaust has become a core element of this liberal European identity. McMahon discusses and Schünemann and Maricut reference a different, progressive narrative of continuously deepening integration (Gilbert, 2008).

Contributors portray narratives as a field of contestation and complexity. Nelsen and Guth's 
religious fundamentalists for example oppose European integration, believing it will precipitate the apocalypse. Schünemann and McMahon discuss battles between Eurosceptic and pro-European narratives in referendum campaigns and political science articles respectively. McMahon's EU scholars disagree about whether the democratic deficit is a genuine problem. Maricut meanwhile shows how the European Parliament and the Council of Ministers prioritise diametrically opposed principles of free movement and security respectively. Petrović analyses such oppositions by using the theoretical concept of transvaluation of values, from Liah Greenfeld's work on nationalism (1992). This states that nations and other political groups partly define their values (or narratives) to mark their difference from rivals. Petrović thus claims that Europe's social model emerged partly from tensions with Ronald Reagan's neoliberal America. While recognising elements of transvaluation of values in the narratives of rival institutions, Maricut emphasises the role of instrumentalisation. This is also a key element for Kaiser, McMahon and Radonić. Radonić suggests that some central and eastern European museums referenced the Holocaust instrumentally to promote their countries' EU accession, while others relativised condemnation of National Socialism by suggesting that Soviet crimes were equally bad.

\section{Actors producing narratives}

Much of discourse analysis in literary studies, where the technique emerged, and in memory studies, is exclusively concerned with discourses alone, with texts. By contrast, a key innovation of this special issue is, as Schünemann puts it, drawing on Foucault, to bring 'the actors back into focus'. Each paper therefore begins by introducing the roles, identities, interconnections and practices of the actors, who devise, disseminate and receive narratives 
of European integration. They do so in complex patterns, usually in some kind of formal or informal institutional structures, whose specific practices shape the narratives.

Several actors normally partake in shaping and contesting narratives. Contributors highlight that political actors interact with diverse social and professional groups to produce narratives of European integration. Among these groups are intellectuals and artists in Kaiser's article, academics in McMahon's and Petrović's, museum organisers in Radonić's and religious leaders in Nelsen and Guth's. Petrović, though he insists on the importance of individual inputs into the contingent evolution of narratives, traces the emergence of common narratives among a whole class of centre-left politicians and public intellectuals. Maricut meanwhile argues, from a policy network perspective, that institutions can also act in practice as corporate narrating actors, developing consistent narratives. Contributors thus treat EU institutions, political parties or social groups as well as cultural institutions such as museums as narrating actors. The organisation of groups in formal institutions, networks, or communities is therefore crucial to the production of narratives. Social science literature on epistemic communities, political and policy networks and communities of practice has increasingly striven to understand these organisational and relational issues (Davis Cross, 2013, p.139-40).

The special issue examines very diverse approaches to linking actors together across borders. The coherence of transnational bonds runs from tight and formal, in European institutions (Kaiser, Maricut), to nebulous, as in the cultural background that links Radonić's museum directors and curators and Nelsen and Guth's Protestant fundamentalists. Between these extremes, there are elements of network connection among McMahon's EU scholars and, to an extent, Nelsen and Guth's Protestants. Schünemann's campaign groups are meanwhile brought together by specific events, in this case referenda, and ideology also links these campaign groups and Petrović's left-wingers. 
A by-product of this transnational approach is a tendency to focus on political or cultural elites. Elites are more transnationally connected than other people (Favell, 2011) and, as at national level in nineteenth century Europe, play a key role in developing the narratives with the greatest impact on the politics of European integration. Kaiser, Maricut, Petrović, and Nelsen and Guth thus all analyse narratives produced by EU political leaders and key institutions. Petrović's emphasis on individual actors, and how their ideologies and attitudes towards European integration are transformed, leads him to focus on pro-EU politicians and public intellectuals with 'a powerful influence on the framing of debates in the EU'. Kaiser's actors include a group specifically selected by the European Commission as representing Europe's cultural elites, while McMahon's research methodology deliberately aims to identify the most prominent EU scholars. Even Schünemann and Nelsen and Guth, who focus to a greater extent on fringe narratives in EU referendum campaigns and Protestantism respectively, identify the most prominent proponents of these narratives. The only major exception to this concentration on high profile elites is Kaiser's analysis of public comments on a Commission internet forum which engaged with the newly developed elite narrative text.

This focus in this special issue on elite narratives neatly complements other transnational approaches, which address discourse among the majority of the population. The latter often apply strongly quantitative approaches, as in the venerable tradition of analysing Eurobarometer results, and studies of what sociologists call the 'horizontal integration' of European populations (Favell, 2011). Qualitative ethnographies and discourse analyses of ordinary citizens' experiences of the EU have also emerged, especially from ethnographers and geographers (Armbruster, Rollo \& Meinhof, 2003).

This special issue is also innovative in extending its focus on narrating actors to their practices of producing, disseminating and receiving narratives within particular social contexts. McMahon and Schünemann's articles demonstrate how political science, 
International Relations and European Studies have recently drawn on sociology of knowledge to develop concepts and notions of actors and practices. However, the roots of the linguistic turn in textual analysis and the habits of intellectual history and political theory have delayed a shift towards analysing actors and their practices. Although constructivism and sociological institutionalism have shown some interest in practices for example (e.g. Adler and Pouliot 2011; Lewis 1998), their main focus remains the study of texts and ideas. The disciplines of sociology and anthropology concern themselves especially with social and political practices. However for European Studies, with the notable exception of French scholarship, they have only recently emerged 'from the wilderness' (Favell \& Guiraudon, 2011, p.1).

Contributors demonstrate that practices of narration impact on the narratives themselves. Kaiser's article for example describes how narratives emerged from interchange between the Commission's instincts for tightly controlled message management and the anarchic individualism of a committee of intellectuals and artists that it set up. Radonić's analysis of museum displays naturally places greater emphasis on the practices of narration than an analysis of written text or speech would. She describes for example how east-central European commemorative museums borrowed the aesthetics of Holocaust memorialisation to legitimise politically instrumental messages that in some cases relativized the Holocaust.

\section{Theories, concepts and methods}

Informed by their diverse disciplinary and cross-disciplinary affiliations, contributors adopt key theoretical approaches for understanding narratives, discourse and identity within the context of European integration. Radonić's memory studies examine, for example, how the past is officially and privately constructed and commemorated. It stresses the competition for 
interpretative authority between different social and political groups within states, but also the attempts to re-narrate the past as shared European history. Developed in France in the 1980s, the Historical Memory School has looked especially at the way that states and their institutions commemorate their past, including in the monuments and museums that Radonić studies. Maricut meanwhile draws on post-positivist approaches from the rich theoretical body of policy narratives literature. Schünemann uses the Sociology of Knowledge Approach to Discourse, which builds on Foucauldian discourse analysis, but is more interested in those who produce discourse.

A key theoretical tension concerns the degree to which the contributors treat the narratives of each individual narrating actor as autonomous or as part of a common cultural discourse. The articles in this special issue all focus on broader cultural narratives, which circulate within a community, told and retold, as long as they sound plausible to story-tellers and listeners (Kaiser 2015: 2; Eder 2006: 257; della Sala 2010: 4; Maza 1996: 1495). For della Sala, this process is crucial for providing political legitimacy (2010: 5). For Klaus Eder, it constructs the boundaries of communities (2006: 258), and for Ian Manners, collective memories (2010: 82). In this volume, Maricut describes policy narratives as designed to achieve 'institutionally constructed' roles. Individual narrators put 'their organization's hat on'.

Contributors nevertheless recognise that cultural narratives are established through multiple unique individual story-telling. Several articles therefore recognise both diversity and coherence among and within different narratives. McMahon for example contrasts the robust narrative of continuous progressive integration towards supranational government with a diversity of accounts of the EU's democratic deficit. Kaiser describes public comments on the 'New Narratives' project as 'a kaleidoscope of opinions'.

Petrović's paper explicitly problematizes this distinction between individual and aggregated narratives, especially where it concerns time. Echoing constructivist and post-modernist 
critiques, he objects to Thomas Risse (2010) tracing British representations of Europe to 'medieval English history', for creating a 'misleading', 'reified view of the social world'. He instead emphasises the 'need for a more flexible and change-sensitive approach' to studying political narratives, which can 'grasp changes in personal ideologies which can ultimately have a major influence'. Other contributors (Maricut, McMahon) by contrast track the rise and fall of multiple narratives over several decades, without strongly problematizing their internal change. Schünemann's snapshot of narratives at a particular time, the emphasis on contingency in Kaiser's account and Nelsen and Guth's intellectual history of the evolution of narratives over time are more compatible with Petrović's argument.

Until the late 1990s, research on ideational dimensions of European integration such as Ronald Inglehart's analyses of opinion poll results (e.g. 1970) generally used positivist, quantitative methods. By contrast, this special issue much more strongly reflects subsequent work, which has been influenced by the linguistic and cultural 'turns'. The articles therefore generally use various forms of comparative qualitative discourse analysis to identify narrative threads from disparate written or spoken texts. These texts include academic works (McMahon, Petrović), religious texts (Nelsen-Guth), political speeches and manifestos (Nelsen-Guth, Petrović, Schünemann), press reports (Maricut), institutional documents (Kaiser, Maricut), and website forum comments (Kaiser). Radonić also treats the aesthetic organisation of museums as texts, alongside more typical textual sources such as museums guides. Kaiser supplements discourse analysis with the other qualitative research techniques of semi-structured interviews and non-participant observation at planning meetings for the Commission's 'New Narrative' project.

Some articles also develop more or less elaborate analytical strategies to identify narrative patterns. McMahon represents normative expressions as the building blocks of narratives in academic works. He codes and quantitatively analyses their degrees of normativity and 
positive or negative tones. Schünemann systematically arranges organisations that campaigned in referenda on the Constitutional Treaty and the Lisbon Treaty along left-right and yes-no axes. Kaiser, Maricut, Nelsen and Guth and, to an extent, McMahon employ the historical narrative approach, tracing how contingent sequences of development shape the production of narratives.

Turning to the contributors' analyses of actors, Kaiser and Maricut study leading figures of formal transnational organisations and their statements. Where contributors research transnational connections of different sorts, other methodological approaches are required. A comparative approach for example identifies transnational narratives and themes by comparing examples across Europe of museums (Radonić), referenda (Schünemann) or political parties (Petrović, Nelsen and Guth). Nelsen and Guth, McMahon and Petrović use a third approach, tracing network connections. These can be formal, like the European Parliament group which links left wing parties; culturally validated, like the EU studies canon of most cited works; or historical, like the linkages which have disseminated millenarian protestant ideologies. Radonić's suggestion that museums create 'Europeanisation of memory' by borrowing 'internationally’ established aesthetics of Holocaust memorialization also implies a network, through which particular cultural elements are diffused.

\section{Conclusion}

Narratives, or stories, are vitally important to European integration, shaping important policies and helping to define the major identities that affect integration. Researchers in European Studies, broadly conceived, are only just coming to appreciate this importance, as they turn from studying discourse and its actual or potential impact on politics, to exploring 
the mechanisms of actors producing and disseminating narratives, their transfer across borders and their contestation in the EU and other polities.

This special issue marks an important step in fostering this new research agenda. It adds two new elements to academic consideration of narratives. First, unlike much previous work, it emphasises the narrating actors, how they are organised and their practices. Second, it highlights a key organisational factor for narratives of European integration. Many of these are formulated by transnational communities and networks of narrating actors or by international institutions that themselves narrate. It remains to be seen how much impact the resulting narratives can have on European and EU politics. Perhaps they provide the EU as a polity with a cultural basis and increase its political stability. Alternatively, the heavy contestation over narratives could actually contribute to undermining the EU's apparently shallow legitimacy and even provoke its downfall and disintegration. 


\section{References}

Adler, E. and Pouliot, V. (2011). International Practices. Cambridge: Cambridge University Press, 2011.

Anderson, B. (2000 [1983]). Imagined communities: reflections on the origins and spread of nationalism. London: Verso.

Armbruster, H., Rollo, C., \& Meinhof, U. H. (2003). Imagining Europe: everyday narratives in European border communities. Journal of Ethnic and Migration Studies, 29(5), 885-899.

Calligaro, O. (2013). Negotiating Europe: EU promotion of Europeanness since the 1950s. Palgrave Macmillan.

Czarniawska, B. (2004). Narratives in social science research. London: Sage.

Davis Cross, M.K. (2013). Rethinking epistemic communities twenty years later. Review of International Studies, 39(1), 137-160.

Della Sala, V. (2010). Political myth, mythology and the European Union. Journal of Common Market Studies, 48(1), 1-19.

Eder, K. (2006). Europe's Borders: The Narrative Construction of the Boundaries of Europe. European Journal of Social Theory, 9(2), 255-271.

Favell, A. (2011). Eurostars and Eurocities: Free movement and mobility in an integrating Europe. New York: John Wiley \& Sons.

Favell, A., \& Guiraudon, V. (2011). Sociology of the European Union: an introduction. Sociology of the European Union, Basingstoke: Palgrave Macmillan, 1-24.

Gilbert, M. (2008). Narrating the Process: Questioning the Progressive Story of European Integration. Journal of Common Market Studies, 46(3), 641-662. 
Greenfeld, L. (1992). Five Roads to Modernity. Cambridge, MA: Harvard University.

Hammack, P. L. (2008). Narrative and the cultural psychology of identity. Personality and Social Psychology Review, 12(3), 222-247.

Hammack, P. L., \& Pilecki, A. (2012). Narrative as a root metaphor for political psychology. Political Psychology, 33(1), 75-103.

Hansen, L., \& Williams, M. C. (1999). The myths of Europe: Legitimacy, community and the ‘crisis' of the EU. Journal of Common Market Studies, 37(2), 233-249.

Hooghe, L. and Marks, G. (2009). A Postfunctionalist Theory of European Integration: From Permissive Consensus to Constraining Dissensus, British Journal of Political Science, 39(1), $1-23$.

Hülsse, R. (2006). Imagine the EU: the metaphorical construction of a supra-nationalist identity. Journal of International Relations and Development, 9(4), 396-421.

Inglehart, R. (1970). Cognitive mobilization and European identity. Comparative Politics, $3(1), 45-70$.

Lewis, J. (1998). Is the 'hard bargaining' image of the Council misleading? The Committee of Permanent Representatives and the local elections directive. Journal of Common Market Studies, 36(4), 479-504.

Kaiser, W. (2007). Christian Democracy and the Origins of European Union. Cambridge: Cambridge University Press.

Kaiser, W. (2015). Clash of Cultures: Two Milieus in the European Union’s 'A New Narrative for Europe' Project. Journal of Contemporary European Studies, 23(3), 364-377. 
Kølvraa, C. (2016). European Fantasies: On the EU's Political Myths and the Affective Potential of Utopian Imaginaries for European Identity. Journal of Common Market Studies, 54(1), 169-184.

Leggewie, C., \& Lang, A. (2011). Der Kampf um die europäische Erinnerung: ein Schlachtfeld wird besichtigt. C.H. Beck.

Littoz-Monnet, A., \& McMahon, R. (2013). Cultures of defining culture: EU cultural policy in the context of the study of culture', in Richard McMahon (ed.), Post-identity? Culture and European Integration, London \& New York: Routledge, 212-34.

Lyotard, J. F. (1979). La condition postmoderne : rapport sur le savoir. Paris: Les éditions de Minuit.

Macdonald, S. (2013). Memorylands: heritage and identity in Europe today. Abingdon: Routledge.

Manners, I. (2002). Normative power Europe: a contradiction in terms? Journal of Common Market Studies, 40(2), 235-258.

Manners, I. (2010). Global Europa: Mythology of the European Union in world politics. Journal of Common Market Studies, 48(1), 67-87.

Manners, I. (2011). Symbolism in European integration. Comparative European Politics, 9(3), 243-268.

Maza, S. (1996). Stories in history: cultural narratives in recent works in European history. The American Historical Review, 101(5), 1493-1515.

Risse, T. (2010). A community of Europeans? Transnational identities and public spheres. Ithaca, NY: Cornell University Press. 
Roberts, G. (2006). History, theory and the narrative turn in IR. Review of International Studies, 32(4), 703-714.

Schimmelfennig, F. (2001). The community trap: Liberal norms, rhetorical action, and the Eastern enlargement of the European Union. International Organization, 55(1), 47-80.

Shenhav, S. R. (2005). Thin and thick narrative analysis: On the question of defining and analyzing political narratives. Narrative Inquiry, 15(1), 75-99.

Shore, C. (2000). Building Europe: The cultural politics of European integration. London: Routledge.

Sjursen, H. (2002). Why expand? The question of legitimacy and justification in the EU's enlargement policy. Journal of Common Market Studies, 40(3), 491-513.

Somers, M. R. (1994). The narrative constitution of identity: A relational and network approach. Theory and society, 23(5), 605-649.

Stråth, B. (2005). Methodological and Substantive Remarks on Myth, Memory and History in the Construction of a European Community. German Law Journal, 6(2), 255-72.

White, H. (1973). Metahistory: the historical imagination in nineteenth-century Europe. Baltimore: Johns Hopkins University Press. 